\title{
LOS CINEASTAS, EL DISPOSITIVO Y LOS CAMPOS SOCIALES TRANSNACIONALES: SER DE ACA Y DE ALLÁ A LA VEZ
}

The filmmakers, the device and the transnational social fields: being from here and from there at the same time

\author{
AnABElla Aurora Castro Avelleyra \\ UNIVERSIDAD DE BUENOS AIRES (ARGENTINA) anabella.castro.a@gmail.com
}

RECIBIDO: 11 DE ABRIL DE 2018

ACEPTADO: 9 DE JULIO DE 2018

\begin{abstract}
RESUMEN: El presente artículo se propone pensar cómo se constituye un campo social transnacional (Levitt y Glick Schiller, 2004; Levitt, 2010) en el film Balseros (Carles Bosch y Josep María Domènech, 2002) y evaluar en qué medida y a partir de qué mecanismos los cineastas y el dispositivo cinematográfico funcionan como agentes activos en él, articulándolo de una manera particular, a través de su función explícita como transmisores de información entre destino y origen. La propuesta es realizar un análisis de la película que mixture la puesta en juego de conceptos provenientes del campo de los estudios migratorios con otros específicamente cinematográficos, vinculando la representación de problemáticas migratorias con las elecciones formales y estéticas del film. De este modo, el texto intenta pensar cómo en la experiencia específica de esta película el proceso de construcción cinematográfica de la migración incide a su vez en la construcción efectiva de los procesos migratorios.
\end{abstract}

PALABRAS CLAVE: cine, Cuba, migraciones transnacionales, documental, identidad.

ABSTRACT: This article aims to analyze how a transnational social field (Levitt and Glick Schiller, 2004, Levitt, 2010) is constituted in the film Balseros (Carles Bosch and Josep María Domènech, 2002) and to evaluate to what extent and through which mechanisms the filmmakers and the cinematographic device function as active agents in it, articulating it in a specific and particular way, through their explicit function as transmitters of information between destination and origin. The proposal of the text is to carry out an analysis of the film that mixes concepts provided by the field of migratory studies with other notions which are specifically cinematographic, linking the representation of migratory problems with the formal and aesthetic choices of the film. In this way, the paper tries to think how in the specific experience of this film the process of cinematographic construction of migration affects in turn the effective construction of migratory processes.

KEYWORDS: cinema, Cuba, transnational migrations, documentary, identity. 


\section{INTRODUCCIÓN}

"La Habana, 1994", nos informa un título impreso sobre imágenes de la ciudad. ${ }^{1}$ Una mujer es sometida a una inspección con un detector de metales. Con abatimiento comunica a la oficial a cargo de la requisa: "Lo único que tengo es tristeza en mi corazón". Inmediatamente después, se presentan tomas de una embarcación repleta de gente. Una voz over nos brinda información que complementa lo que estamos viendo: el frustrado secuestro de una lancha que cotidianamente hace el breve trayecto hacia Regla. Luego, una sucesión de planos del "Maleconazo", nombre que se le dio al inusual estallido social que prosiguió a este hecho. Así, en breves minutos, Balseros (Carles Bosch y Josep María Domènech, 2002) ${ }^{2}$ nos introduce a uno de los puntos de inflexión más determinantes en la historia político-social de Cuba: la crisis de los balseros. ${ }^{3}$ Sus causas fueron múltiples, como el propio documental deja entrever. Por un lado, el deterioro de la calidad de vida de los cubanos a partir de la profunda crisis económica desatada por el derrumbe del bloque socialista europeo, ${ }_{4}^{4}$ pero también la negativa por parte del gobierno estadounidense de otorgar el número de visas pautado en los acuerdos migratorios de 1984.5 Con esto, se impedía que los ciudadanos que quisieran emigrar pudieran hacerlo de acuerdo a la ley y se alentaba la emigración ilegal. El film de Bosch y Domènech no se detiene sencillamente en estas explicaciones, sino que se encarga de seguir durante más de un lustro las trayectorias de siete de los sujetos que decidieron lanzarse al mar, ${ }^{6}$ así como las de sus familias, a un lado y al otro del estrecho de Florida. La dupla de directores españoles comenzó el rodaje en La Habana en 1994 como registro periodístico para un programa televisivo. Lo prosiguió ocho meses después, ingresando a la base militar de Guantánamo, donde los balseros se encontraban recluidos tras su

\footnotetext{
${ }^{1}$ Las palabras señaladas en itálicas en el título del artículo provienen de la "antropología del movimiento" propuesta por Alain Tarrius (2000) y explicada más adelante en este texto. Como se verá, el autor habla del "ser de aquí y de allá a la vez" (Tarrius, 2000: 41), idea que nos parece complementaria al concepto de campo social transnacional (Levitt y Glick Schiller, 2004; Levitt, 2010) y apropiada para la reflexión en torno a Balseros.

2 Balseros es un film documental de producción española, que fue rodado en Cuba y Estados Unidos, involucrando actores sociales cubanos y trabajando la problemática migratoria cubano-estadounidense.

3 Con este nombre se conoce al éxodo de miles de cubanos que intentaron emigrar hacia Estados Unidos en balsas rústicas luego de que el gobierno cubano eliminara momentáneamente las restricciones a las salidas ilegales el 12 de agosto de 1994, debido a los eventos anteriormente mencionados. Una semana después, el gobierno estadounidense presidido por Bill Clinton notificó que no se permitiría el ingreso de los balseros al país y que serían concentrados en las bases militares de Guantánamo y Panamá. El 9 de septiembre de 1994 se firmó un acuerdo migratorio entre ambos países, por el cual Estados Unidos se comprometía a otorgar un mínimo de 20.000 visas anuales y Cuba a controlar las salidas ilegales. El 2 de mayo de 1995 se firmó una ampliación a ese acuerdo, a partir de la cual se garantizó el ingreso legal a Estados Unidos de los detenidos en las bases (Arboleya Cervera, 2013).

${ }^{4}$ El 29 de agosto de 1990 se habló por primera vez del Período especial en tiempos de paz, forzado por el derrumbe del bloque socialista europeo. Esto -sumado a un recrudecimiento del bloqueo estadounidense- condujo a una crisis económica que afectó considerablemente las condiciones de vida de la población. Se redujo la canasta familiar y, por lo tanto, el consumo de calorías y proteínas. Inconvenientes en el acceso al combustible produjeron deficiencias en el servicio de transporte y "apagones” periódicos. Se incrementó también la problemática habitacional, debido a la imposibilidad de construcción de nuevas viviendas y al mantenimiento de las ya existentes. En el intento de hacer frente a la crisis, se tomaron una serie de medidas, como la promoción del turismo, la despenalización de la circulación de divisas y la apertura a inversiones extranjeras, entre otras (Alonso Tejada, 2006).

5 A partir de estos acuerdos, el gobierno estadounidense, bajo la presidencia de Ronald Reagan, se comprometía a otorgar hasta 20 mil visas anuales a ciudadanos cubanos (Arboleya Cervera, 2013).

${ }^{6}$ Se trata de Méricys González, Misclaida González, Juan Carlos Subiza, Oscar del Valle, Guillermo Armas, Miriam Hernández y Rafael Cano.
} 
fallido intento migratorio. En esa ocasión, registraron mensajes de los detenidos para sus familiares, ${ }^{7}$ a quienes también filmaron al momento de recibirlos. Luego, acompañaron su arribo a Estados Unidos y los momentos iniciales de contacto con ese país, para finalmente reencontrarse con ellos -y con sus familiares, volviendo a propiciar el flujo de mensajes entre ambos espacios- cinco años después. En este sentido, la perspectiva diacrónica privilegiada por la película, el recurso a elementos propios de la modalidad de representación documental interactiva / participativa (Nichols, 1997, 2001; Weinrichter, 2004) y la intimidad procurada con los actores sociales a partir de la labor de los cineastas como facilitadores de la comunicación familiar en el film, habilita reflexionar sobre la posible conformación de un tipo particular de campo social transnacional (Levitt y Glick Schiller, 2004; Levitt, 2010).8

Por ello, en el presente artículo se propone pensar cómo se constituye ese campo y en qué medida y a partir de qué mecanismos los cineastas y el dispositivo cinematográfico funcionan como agentes activos en él, articulándolo de una manera particular, a través de su función explícita como transmisores de información entre destino y origen. Se intentará identificar cómo se configuran las cadenas y redes migratorias (Pedone, 2010) y cómo se estructuran las estrategias migratorias y los proyectos migratorios familiares (Pedone, 2010), pensando al interior de ellos un caso de maternidad transnacional (Hondagneu-Sotelo y Avila, 1997). Se vinculará la representación de estas problemáticas con las elecciones formales y estéticas de la película. Para ello, servirá pensar en algunas estrategias propias de los documentales interactivos / participativos (Nichols, 1997, 2001; Weinrichter, 2004) identificables en el film y los elementos narrativos desplegados por los cineastas. En este sentido, se aspira a realizar un análisis de Balseros que mixture la puesta en juego de los conceptos provenientes del campo de los estudios migratorios con otros específicamente cinematográficos. De este modo, se propone pensar cómo en la experiencia específica de esta película el proceso de construcción cinematográfica de la migración incide a su vez en la construcción efectiva de los procesos migratorios.

Dada la compleja relación político-diplomática entre Cuba y Estados Unidos, en este documental de temática migratoria tanto la labor de los directores como el propio dispositivo cinematográfico inciden en el mantenimiento de intercambios entre origen y destino. En su artículo "Cadenas y redes migratorias: propuesta metodológica para el análisis diacrónicotemporal de los procesos migratorios", Claudia Pedone sostiene:

La reconstrucción de la historia individual y familiar de un/a migrante, desde una perspectiva diacrónica, permite desentrañar las fases de un proceso que, en el marco de los procesos de globalización económica, adquiere connotaciones específicas y perpetúa otras heredadas de antiguas estructuras políticas y socioeconómicas (2010: 102).

No resulta casual, entonces, que Balseros estructure su relato justamente a partir de la presentación de historias individuales y familiares de migrantes desde una perspectiva diacrónica, en el intento de abordar críticamente un proceso socio-económico-político determinante en la vida de muchos cubanos. El trabajo sostenido en el seguimiento de las trayectorias migratorias de

\footnotetext{
${ }^{7}$ Los familiares de Guillermo Armas se encontraban ya en Estados Unidos. Los de Miriam Hernández, en Batabanó, Cuba. El resto, en La Habana.

8 Se explicará más adelante este concepto, proveniente del campo de los estudios migratorios.
} 
siete actores sociales y sus familias durante un lapso superior a seis años dota a este film de unas características poco comunes. $\mathrm{Y}$ es esa perspectiva la que enriquece el abordaje de una problemática tan compleja como es la emigración de Cuba a Estados Unidos. El devenir de cada experiencia migratoria particular constituye un aporte a la reflexión en torno a un proceso político más amplio, en el que se enmarca. Así, este film de factura española se convierte en esencial para pensar a la sociedad cubana en lo referido a los vínculos que mantiene con los ciudadanos que emigran, con los que sostienen un contacto con los emigrados (a partir de las comunicaciones y la recepción de remesas) y con aquellos que desean emigrar. También presenta una lectura crítica respecto al devenir de los migrantes en la sociedad de destino, cuyas experiencias efectivas como inmigrantes distan de la construcción imaginaria que los llevó a emigrar.

La crisis económica del Período especial en tiempos de paz afectó también al quehacer cinematográfico que, hasta ese momento, era en mayor medida producido por el Instituto Cubano del Arte e Industria Cinematográficos (ICAIC). La disminución de presupuesto puso en jaque la posibilidad de realizar películas y se incrementaron significativamente las coproducciones, principalmente con España. Algunos cineastas de este país también dirigieron films producidos por capitales netamente españoles, pero que abordaban problemáticas cubanas e incluían actores de esa nacionalidad. Balseros es uno de estos casos. Estas producciones proponen por lo general miradas alternativas y complementarias a las de los films de directores cubanos. Bosch y Domènech hacen lo que ningún director cubano hizo: un documental cuyo tema central sea la crisis de los balseros. ${ }^{9}$ La nacionalidad española de los realizadores les permite también tener acceso al rodaje tanto en territorio cubano como estadounidense, estrategia indispensable para su participación, como se intenta plantear en el presente artículo, en la configuración de un campo social transnacional.

A partir de estas características, se puede concebir a Balseros como un film transnacional ya que, como se ha indicado, si bien es de producción y dirección españolas, trabaja problemáticas que atañen a los pueblos de Cuba y Estados Unidos, ${ }^{10}$ el rodaje se realizó en estos dos países y los actores sociales que aparecen en el documental son de estas nacionalidades. En este sentido, consideramos que se puede pensar al film a partir de lo que Mette Hjort (2009) llama transnacionalismo afinitivo. Éste, de acuerdo a la autora, conduce a intercambios entre aquellos que se parecen entre sí, ya sea en términos étnicos e idiomáticos o a partir de un conjunto de prácticas comunes o historias de interacciones compartidas. Hjort sostiene que este tipo de transnacionalismo no necesariamente se basa en similitudes culturales de antaño, sino que puede deberse a problemas compartidos en la actualidad o a partir del descubrimiento de cuestiones en otros contextos nacionales que podrían ser relevantes para problemas vivenciados en el contexto local.11 Se considera aquí que en función del interés por la problemática migratoria

\footnotetext{
${ }^{9} \mathrm{El}$ propio Carles Bosch sostuvo en una entrevista realizada doce años después del estreno del film, "creo que es una pena que los cubanos no hayan podido explicar más ese tema” (González Breijo, 2014).

10 Y que, como se verá a continuación, puede relacionarse fácilmente con problemáticas contemporáneas propias de España.

${ }^{11}$ En este sentido, Carles Bosch expresó en una entrevista publicada en el periódico El país: "Aunque ésta sea la vida de unos cubanos que quieren marcharse a Estados Unidos, también puede simbolizar la historia de un marroquí que cruza el Estrecho en patera" (Ramos Martín, 2003: párr. 5).
} 
experimentado en España desde la década del noventa, a partir del incremento del número de inmigrantes en el país, ${ }^{12}$ podría comprenderse un tipo de transnacionalismo afinitivo con el cine cubano, favoreciendo el trabajo sobre la cuestión de las migraciones. ${ }^{13}$ Por supuesto que entre ambos países este tipo de transnacionalismo se explica también por una historia común de larga data, inscrita ya en los orígenes transculturales de la identidad cubana tal como la estudió Fernando Ortiz (1978). Se considera, por lo tanto, que la historia compartida con Cuba y la propia preocupación española por la problemática migratoria son factores a tener en consideración en el análisis de esta película. En torno al concepto de lo transnacional en los estudios fílmicos, Will Higbee y Song Hwee Lim (2010) proponen tomar en cuenta las implicaciones estéticas, políticas o económicas que la colaboración transnacional pudiera producir. Si el transnacionalismo afinitivo formulado por Hjort permite pensar en las afinidades propiciadoras de los intercambios transnacionales entre cinematografías, el transnacionalismo crítico promovido por Higbee y Lim procura estar alerta a una política de la diferencia. Así, entre afinidad y diferencia se puede pensar el carácter transnacional de este film.

\section{MiGRACIONES TRANSNACIONALES}

En el presente apartado se desarrollarán una serie de conceptos teóricos provenientes principalmente del campo de los estudios sobre migraciones transnacionales, que se considera permiten conjeturar algunas hipótesis de interés en torno a Balseros.

Como se ha señalado anteriormente, este documental conduce a una reflexión en torno a cuestiones tales como el concepto de Estado-nación y las cinematografías nacionales. Respecto a esto último, el film admite ser pensado como transnacional, por los factores ya planteados. Tanto sus características de realización como las historias que narra ponen el acento también en las nociones de Estado-nación y sociedad. Enfrentadas a lo que se conoce como nacionalismo metodológico, ${ }^{14}$ Peggy Levitt y Nina Glick Schiller (2004) proponen una reformulación del concepto de sociedad, que no la limite a las fronteras de un Estado-nación. En este sentido, destacan que los migrantes pueden incorporarse al Estado receptor manteniendo a la vez relaciones transnacionales duraderas, constatándose así una "simultaneidad del vínculo" (Levitt y Glick Schiller, 2004: 67). Ésta supone "llevar una vida que incorpora las instituciones, las actividades y las rutinas diarias que se sitúan tanto en el país de destino como transnacionalmente" (ibídem: 62). Esto conlleva a su vez modificaciones en las constituciones identitarias y en los modos de comprenderlas. Por lo tanto, resulta de interés relacionar esta noción de "simultaneidad del vínculo" con las ideas de Alain Tarrius, según quien, en estas

\footnotetext{
12 Tras su incorporación efectiva en la Unión Europea, en 1986, España pasó de ser un país eminentemente generador de emigrantes a convertirse en receptor de inmigración (Villar-Hernández, 2002). Esto condujo a que la problemática inmigratoria cobrara interés social, político y también cinematográfico, ya que algunos films comenzaron a ocuparse de una temática anteriormente no abordada (Villar-Hernández, 2002; Tal, 2011).

13 Películas como Balseros o 90 millas (Francisco Rodríguez, 2005) abordan la problemática de la emigración de Cuba a Estados Unidos, pero otras como Cosas que dejé en La Habana (Manuel Gutiérrez Aragón, 1997) o Flores de otro mundo (Icíar Bollaín, 1999) se centran en la inmigración cubana en España.

${ }^{14} \mathrm{El}$ nacionalismo metodológico tiene que ver con "el dar por sentado que las fronteras del Estado-nación delimitan y definen la unidad de análisis” (Levitt y Glick Schiller, 2004: 65). Al mismo tiempo, esto lleva a confinar los estudios a las fronteras de un único Estado-nación.
} 
circunstancias, "el vínculo con el lugar y las diversas manifestaciones sedentarias que lo generan" (2000: 40), erigidas durante mucho tiempo como legitimadoras de las identidades, pierden su sentido y jerarquía. Los sujetos, en realidad,

improvisan, precisamente a partir de sus experiencias circulatorias, identidades mestizas entre universos cercanos y lejanos, transnacionales frecuentemente, imponiendo a la oposición clásica entre los nuestros y los suyos, entre ser de aquí o de allá, otra forma triádica, es decir en constante proceso: el ser de aquí, el ser de allá, el ser de aquí y de allá a la vez (Tarrius, 2000: 41).15

Las experiencias y las identidades de los actores sociales en Balseros se construyen -en mayor o menor medida, como se verá- de esa forma tríadica. La simultaneidad reconfigura el concepto de sociedad, que pasa a conformarse de modo transnacional. Se establecen, así, campos sociales transnacionales (Levitt y Glick Schiller, 2004; Levitt, 2010) que conectan actores a través de las fronteras. Se trata de un concepto de importancia para la lectura aquí propuesta del film, ya que, de acuerdo a Peggy Levitt y Nina Glick Schiller, permite comprender la migración más allá de su experiencia directa, a partir de las relaciones sociales que se establecen entre aquellos que se desplazan y quienes no. De este modo, el término permite considerar cómo incluso las vidas de quienes no se movilizan son "influenciadas regularmente por gente, ideas, y objetos materiales lejanos" (Levitt, 2010: 19). Así, este concepto permitirá pensar cómo no sólo los siete balseros que emigran sino también los familiares que los esperan en Estados Unidos y los que permanecen en Cuba (e incluso sujetos que exceden al grupo familiar, como vecinos, funcionarios, empleadores, etc.) son parte del complejo proceso migratorio que conduce a una reformulación de la sociedad que excede los límites de un Estado-nación. En esto juegan un papel las redes y cadenas dentro del campo, que conectan a personas que mantienen relaciones transnacionales con aquellas que no las tienen, pero reciben el tipo de influencias anteriormente mencionadas. De acuerdo a esta teoría, entonces, los campos sociales transnacionales se conforman a partir de los vínculos entre origen y destino. Lo que intentará proponer el presente análisis es que, en el caso de las experiencias documentadas en Balseros, además de todos los agentes mencionados por Levitt y Glick Schiller, también los directores y el dispositivo cinematográfico contribuyen a la experiencia compleja de la migración.

Claudia Pedone (2010) señala que las cadenas migratorias tienen que ver con la transferencia de información sobre aspectos de la sociedad de destino, que colabora en el proceso de toma de decisión del viaje y es obtenida a través de familiares y amigos, así como también con los apoyos materiales que éstos pudieran brindar en su acogida al momento de concretar el traslado. Las redes migratorias, por su parte, tienen un carácter transnacional e institucional. Entre ellas, de acuerdo a la autora, se incluyen las políticas de estado de los países de origen y destino, los servicios sociales y las asociaciones religiosas. Se establecen así diversos tipos de relaciones, algunas de las cuales, señala Pedone, se articulan verticalmente, a partir de actores que detentan poder en lo referido al acceso al trabajo y la vivienda. Otras lo hacen horizontalmente,

\footnotetext{
15 Tarrius, a partir de su "antropología del movimiento" (2000: 45), propone superar la terminología de la migración: "Inmigración, emigración, migración aún remiten demasiado a este universo del otro distante, diferente, étnico" (2000: 60). En este artículo se considera que los modos en que los movimientos se construyen en Balseros aún no remiten a un desarrollo de los "territorios circulatorios" tan extremo como propone Tarrius. En este sentido se cree correcto seguir refiriendo, en este caso, a procesos migratorios, inmigrantes y emigrados.
} 
como es el caso de amigos o familiares previamente establecidos en el lugar de llegada. Todas estas articulaciones se aprecian en los distintos vínculos que entablan los actores sociales en la película y que incluyen también a los cineastas y al dispositivo cinematográfico. Interesa recalcar, para el presente análisis, que esta autora considera a los modos en los que circula la información, así como su cantidad y calidad como "un elemento de vital importancia para la dinámica y consolidación de las redes” (Pedone, 2010: 108). Otro aspecto señalado por la autora, que será de interés para este análisis, tiene que ver con que la decisión de migrar no es siempre individual, sino que en muchas oportunidades forma parte de un proyecto migratorio familiar. En algunos casos, tal proyecto es encabezado por mujeres que emigran sin sus hijos, quienes permanecen en origen, al cuidado de otros miembros de la familia. Se establece así una variante en los modos de organización y las prioridades de la maternidad, que Pierrette Hondagneu-Sotelo y Ernestine Avila (1997) denominan como "maternidad transnacional". En estos casos, "los significados de la maternidad son reorganizados para adaptarse a estas separaciones espaciales y temporales" (Hondagneu-Sotelo y Avila, 1997: 548, traducción propia). Las madres transnacionales, señalan las autoras, intentan sostener las conexiones familiares estableciendo lazos emocionales a través de cartas, llamados telefónicos y el dinero que envían. Los proyectos migratorios familiares en Balseros son varios. Entre ellos se destacan el de Guillermo Armas, que fue encabezado por su mujer y su hija, por lo cual a él lo moviliza el objetivo de la reunificación familiar, y el de Miriam Hernández, caso que se encuadra en la lógica de la maternidad transnacional.

Levitt y Glick Schiller (2004), por su parte, dan cuenta de cómo los migrantes promueven algunos vínculos familiares y dejan de lado otros, de acuerdo a sus necesidades particulares. Esto se aprecia especialmente en el film en el caso de Oscar del Valle. La supresión del vínculo con sus familiares pone de relieve particularmente el rol de los cineastas y el dispositivo cinematográfico, ya que son ellos quienes restablecen una comunicación que, de otro modo, probablemente hubiera permanecido quebrantada. Señalan Levitt y Glick Schiller (2004), a su vez, cómo tanto los niños que no regresan a origen como los que nunca emigraron, pero fueron criados en ambientes permeados por recursos y remesas provenientes de destino, viven una experiencia que no está territorialmente limitada. Aquí, los casos de las hijas de Guillermo y Miriam son fundamentales. Mientras que, a la primera, cuando su padre se encuentra aún en Cuba, su madre le narra historias y muestra fotografías de su vida en La Habana, la segunda recibe juguetes y ropa que envía su madre de Estados Unidos, tiene acceso a determinadas comodidades provistas por el envío de remesas y mantiene un diálogo periódico con su progenitora -y, posteriormente, con su hermanita estadounidense- comunicándose telefónicamente experiencias de su cotidianidad. Es que, como se señaló anteriormente, el concepto de sociedad no puede comprenderse ya a partir de las fronteras del Estado-nación. De este modo, "los individuos dentro de estos campos están influidos, a través de sus actividades y relaciones cotidianas, por múltiples conjuntos de leyes e instituciones" (Levitt y Glick Schiller, 2004: 67). En el caso de Balseros se manifiesta claramente cómo los sujetos migrantes están regidos por leyes e instituciones estadounidenses y cubanas. Su actividad responde a distintos Estados, como se aprecia tanto en el momento de la emigración como en los trámites de reunificación. Si Benedict Anderson (1993) se refería a las naciones como "comunidades imaginadas" se podría pensar aquí más bien en comunidades transnacionalmente imaginadas. Y si, de acuerdo a Anderson, en la imprenta se encuentra el germen 
de las primeras, el cine -y sobre todo uno de las características señaladas en el apartado anterior para Balseros- podría pensarse como factor significativamente contribuyente al desarrollo de las segundas.

\section{PENSANDO BALSEROS}

Balseros se originó como un registro periodístico para el programa 30 minuts de la Televisió de Catalunya. En ese primer momento, los directores documentaron con avidez la agitación que se vivía en La Habana a partir de la autorización gubernamental para que los ciudadanos pudieran abandonar el país en balsas con destino a Estados Unidos. Estos hechos fueron instigados por la fuerte crisis económica que azotó a Cuba a partir del derrumbe del campo socialista europeo, el recrudecimiento del bloqueo estadounidense y la negativa por parte de la Sección de Intereses de Estados Unidos en Cuba de entregar la cantidad de visas necesarias para que todas las personas que quisieran emigrar pudieran hacerlo de modo legal. La Ley de Ajuste Cubano -que rige desde 1966 y considera a los inmigrantes cubanos como asilados políticos, brindándoles un estatus migratorio especial- contribuyó también a este proceso.

El fenómeno migratorio que registra el documental de Carles Bosch y Josep María Domènech, conocido como crisis de los balseros (1994), reforzó un dato que ya se había verificado con el éxodo del Mariel (1980):16 sin importar la connotación política que el país receptor (Estados Unidos, en ambos casos) quisiera darle al hecho a partir de la ley anteriormente mencionada, las motivaciones de la emigración ya no eran las propias del exilio histórico (aquel comprendido entre los años 1959 y 1973); ${ }^{17}$ ahora los emigrantes eran movidos principalmente por razones económicas y, en algunos casos, de reunificación familiar (Arboleya Cervera, 2013). Todo esto conllevó modificaciones tanto en la concepción política y social sobre los emigrados como en sus modos de construcción cinematográfica. ${ }^{18}$ En este último aspecto, como ya hemos señalado en otras oportunidades, la "superación de concepciones petrificadas de identidad y su comprensión como un fenómeno histórico y móvil permitió la complejización del acercamiento cinematográfico al tema, asumiendo a las experiencias derivadas de los movimientos migratorios como fuertemente incidentes en la constitución identitaria" (Castro Avelleyra, 2016: 30).

\footnotetext{
${ }^{16}$ En abril de 1980 se produjo la toma de la embajada del Perú por un grupo de personas que querían emigrar. Por el transcurso de seis meses, el gobierno cubano autorizó el arribo de embarcaciones desde Estados Unidos al puerto del Mariel para que recogieran a aquellos que deseaban abandonar el país por esa vía (Arboleya Cervera, 2013).

${ }^{17}$ La "primera oleada" de este exilio histórico se produjo entre enero de 1959 y finales de 1962 y estuvo compuesta por individuos vinculados a la dictadura de Fulgencio Batista y los sectores que se vieron directamente afectados por las políticas sociales de la Revolución. A partir de la apertura del puerto de Camarioca en 1965 y hasta 1973 se marchó del país con destino a Estados Unidos el remanente de este grupo. Se trató, en estos casos, de personas motivadas por cuestiones políticas. Esto se modificó, como hemos señalado, a partir de las salidas por el Mariel en 1980 y, sobre todo, desde la década del noventa por la injerencia de la crisis económica conocida como Período especial en tiempos de paz (Arboleya Cervera, 2013).

${ }^{18}$ Desde el discurso oficial se produjo un viraje lexical que dejó de lado la nominación de "exiliados" para pasar a hablar de "emigrados", destacando las motivaciones económicas de la partida (Arboleya Cervera, 2013). En el cine es también a partir de la década del noventa que la problemática migratoria comienza a ser trabajada de modo persistente y crítico (Fornet, 2000; Díaz, 2001, 2008; Almazán del Olmo, 2007).
} 
Estrenada en 2002, con imágenes registradas a partir de 1994, Balseros se inscribe en este tipo de tratamiento del fenómeno migratorio e identitario. El documental acompaña la experiencia migratoria de siete cubanos, dando cuenta de los vínculos con sus familiares. La película presenta una estructura organizada en cuatro partes. La inicial se ubica en La Habana, en 1994, momento cumbre del éxodo de balseros. Ese tramo del film registra la construcción de las precarias embarcaciones y las motivaciones de la emigración en cada caso particular. Un segundo segmento es filmado ocho meses después, cuando los protagonistas se encuentran detenidos en Guantánamo, donde fueron derivados tras ser interceptados en altamar antes de alcanzar suelo estadounidense. Luego se muestra la salida de la base militar y el ingreso a Estados Unidos. Por último, el documental los reencuentra cinco años más tarde ya asentados en este país. Todas estas imágenes se intercalan con las de los familiares que permanecieron en Cuba.

Un dato significativo, que resulta de especial interés para el presente análisis, es el papel que desempeñan los directores del film y el propio dispositivo cinematográfico al constituirse en facilitadores de la comunicación entre origen y destino de un modo que se explicita a partir de decisiones formales. Entre ellas se destacan la mirada y el discurso a cámara como modalidad de comunicación directa entre familiares, la inclusión de la voz de los realizadores, proveniente de fuera de campo, que denota su participación activa en los intercambios entre los actores sociales, y especialmente el tipo de montaje utilizado en las escenas correspondientes a las comunicaciones. De modo recurrente, se apela al montaje paralelo para disponer los planos en los que los emigrados observan en una pantalla la vida de aquellos que permanecen en origen (y viceversa) y los planos correspondientes a la acción efectiva que el video reproduce. Así, por ejemplo, un plano que presenta a la hija de un emigrado bailando en Cuba es sucedido por otro que encuadra al padre viendo esa imagen a través de una pantalla. Un nuevo empalme, por corte, nos devuelve la imagen de la niña bailando y posteriormente, otra vez, el plano que encuadra al padre que mira esa imagen en una pantalla. Este plano nos permite también apreciar su reacción gestual y verbal ante lo que está viendo. El montaje empleado en este tipo de escenas, que se reiteran profusamente a lo largo del film, explicita el rol de los realizadores en tanto mediadores en las comunicaciones. Es particular, también, el uso del montaje en las escenas de llamadas telefónicas. En éstas se alternan sucesivamente dos planos. En el primero, la imagen está compuesta de tal forma que el sujeto que sostiene el teléfono ocupa la mitad derecha del plano, mientras en la mitad izquierda se observa, de fondo, el locutorio desde el que realiza el llamado. En el plano posterior, la persona que sostiene el auricular en Cuba ocupa la mitad izquierda de la imagen, mientras que en la derecha se observa el living de su casa. A través del fundido encadenado se producen los pasajes entre ambos planos. En algunos momentos, ese fundido encadenado conduce a que ambos planos confluyan configurando una composición correspondiente a la de pantalla partida. Este tipo de montaje hace confluir los espacios de Estados Unidos y Cuba, poniendo de manifiesto, en primer lugar, el vínculo transnacional a partir de la comunicación telefónica, pero también el rol ejercido por los cineastas en la particularidad de la puesta en escena de esa comunicación: hay una cámara registrando a cada lado del auricular y el montaje de esos planos colabora a la fusión parcial de ambos espacios, que se muestran tan próximos como distantes. 


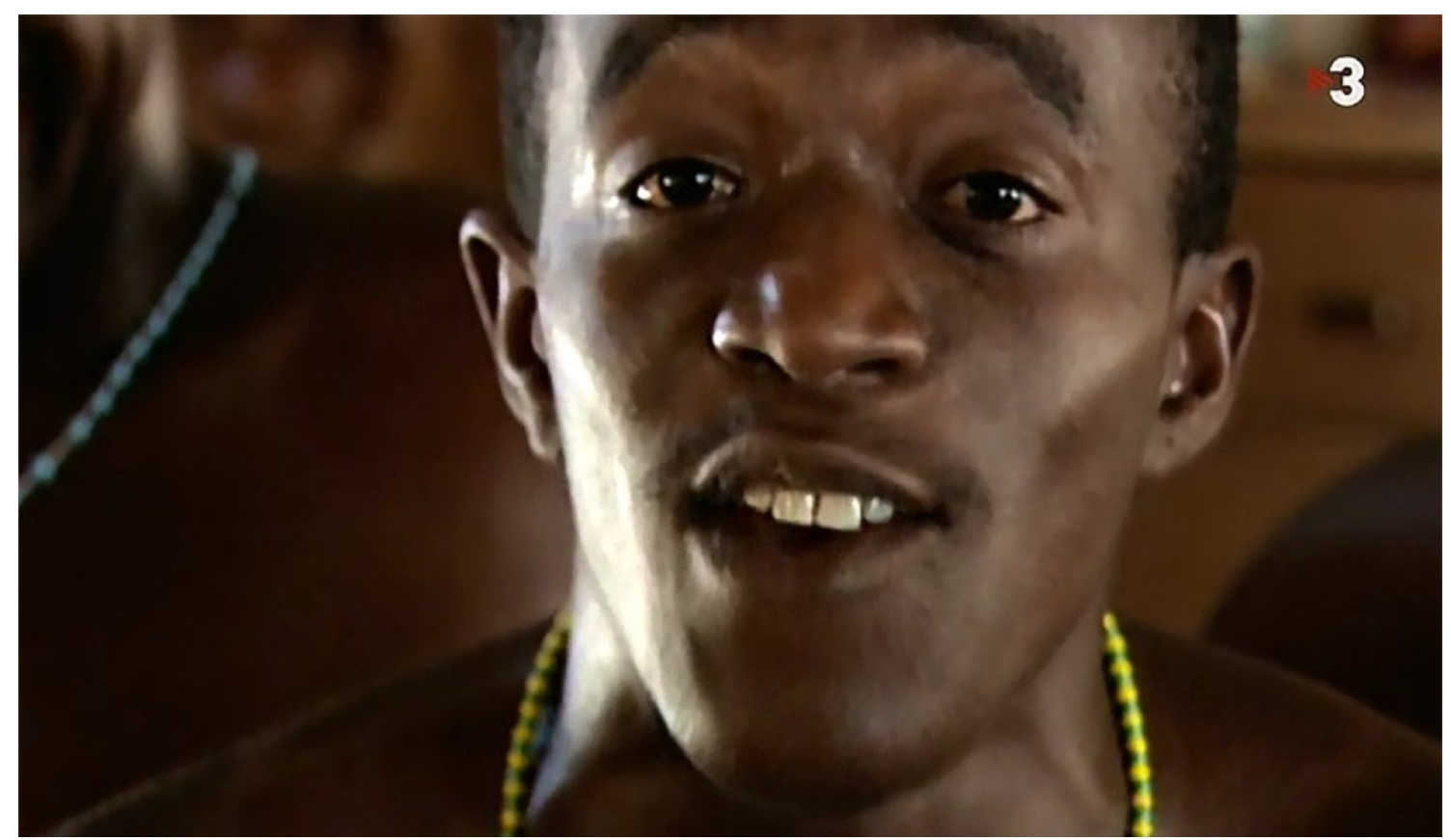

Imagen 1: Oscar habla a cámara desde Guantánamo para enviarle un mensaje personal a su esposa.

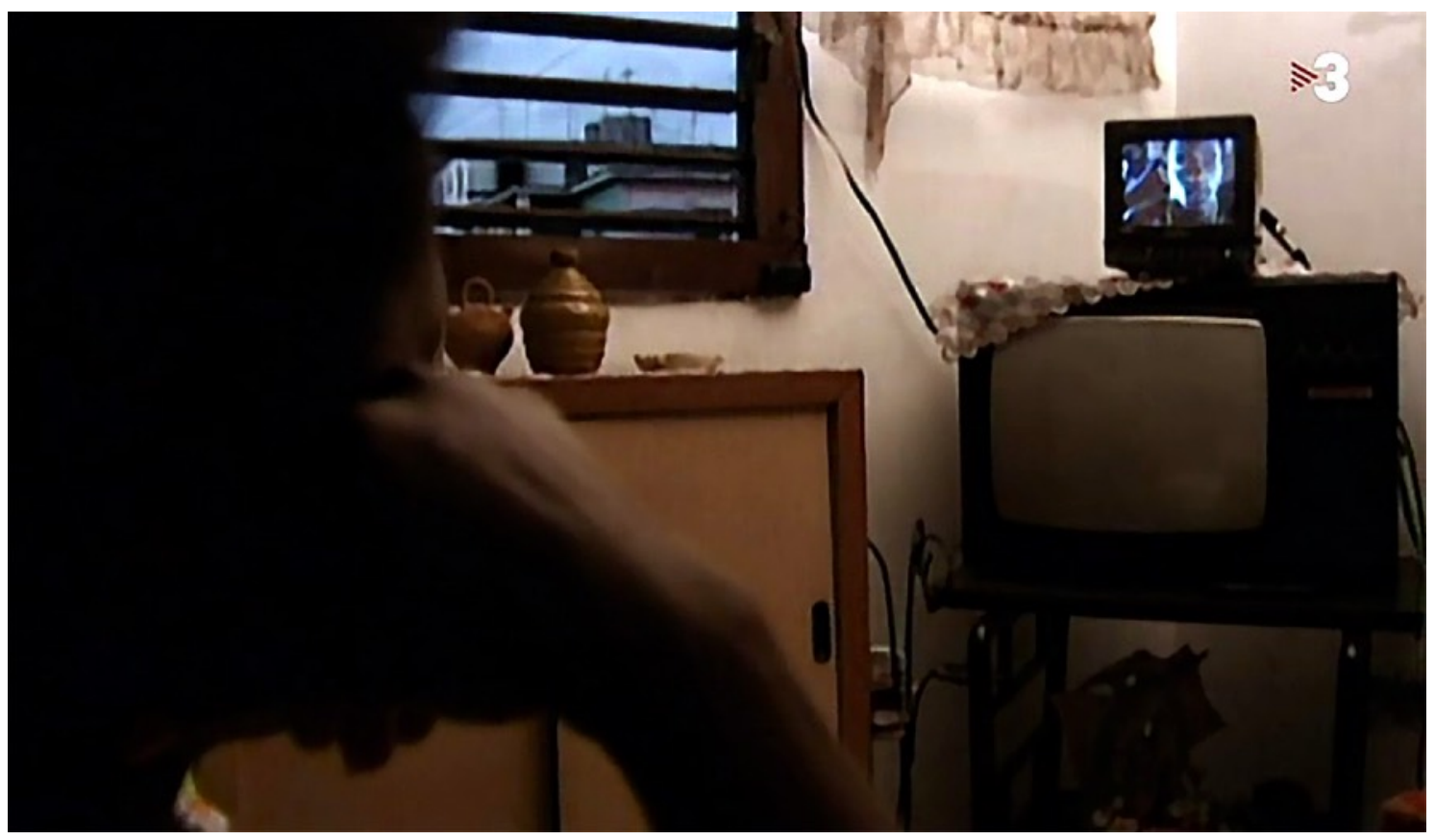

Imagen 2: La esposa de Oscar recibe el mensaje en su hogar en La Habana.

El rol desempeñado por los directores -apoyado en las posibilidades del dispositivo cinematográfico- en tanto posibilitadores de la comunicación entre los migrantes y sus familiares es así destacado de modo permanente a lo largo del film y se percibe especialmente en el momento en que los emigrados se encuentran detenidos en Guantánamo, ya que logran establecer comunicación con sus familias incluso estando en la base militar que Estados Unidos conserva en territorio cubano. Es ese, además, el primer momento en que asumen este rol. De 
aquí en adelante, los emigrados se comunican con sus familiares a través de los realizadores y con la mediación del dispositivo cinematográfico. En su propia alocución, desde Guantánamo, se explicita esta mediación. Los balseros dirigen su discurso a la cámara. Esa mirada a cámara manifiesta la interpelación directa a los familiares, explicitando a su vez el lugar de los realizadores y del dispositivo cinematográfico como intermediarios en esa comunicación. La imagen de Oscar, dirigiéndose a su mujer mirando directamente a la cámara (Imagen 1) es sucedida, a través de un fundido encadenado, por un plano que muestra esa misma imagen siendo reproducida en un televisor, frente al cual se encuentra su esposa, en el living de su casa (Imagen 2). Luego se sucederán, a partir de un montaje paralelo, las imágenes de Oscar hablando a cámara en Guantánamo y las de su familia viendo esa misma imagen reproducida en su hogar. La misma estructura se repetirá luego con otros emigrados. La intervención activa de los cineastas y del dispositivo cinematográfico, particularmente explicitada mediante el montaje de las bandas de imagen y sonido, se observa también, especialmente, en escenas en las que el plano de un sujeto que da su testimonio es sucedido por un plano registrado en otra locación, pero sobre el que aún se escucha la voz de la toma anterior narrando lo que la imagen del plano actual nos muestra, hasta dar paso a la sincronización del sonido de la toma vigente. Por ejemplo, en una escena la hermana de Rafael narra, en su living en La Habana, cómo su tío en Miami tiene todo listo para recibirlo. Mientras su voz continúa enumerando los preparativos que su familiar realiza en destino, se pasa a un plano del tío caminando por la habitación lista para su recepción. La voz que escuchamos sigue siendo la de su hermana en Cuba, pero la imagen ya nos muestra al tío en Estados Unidos. Luego, la voz de la hermana será reemplazada por la del tío, sincronizada ya con la banda imagen, que continuará narrando su colaboración en la recepción de Rafael y sus expectativas al respecto. Previamente, la imagen de la hermana de Rafael en el living de La Habana había sucedido, a partir de un fundido encadenado, a la del propio Rafael dirigiéndose a la cámara en Guantánamo. Este tipo de estructura compleja hilvana sujetos, interrelaciona e integra experiencias y hace confluir tiempos y espacios, colaborando fuertemente con la idea de construcción de un campo social transnacional. De este modo, consideramos que los realizadores asumen un rol activo en su constitución, en la que se explicita a su vez la mediación del dispositivo cinematográfico, uniendo origen y destino a través del establecimiento de distintos mecanismos de comunicación: filmación del momento en que se escriben y se leen cartas, registro audiovisual de los llamados telefónicos en origen y destino, mostración de la vida cotidiana en ambos lados y discurso a cámara como interpelación directa a los familiares, entre otros. ${ }^{19}$ El empleo sistemático de los fundidos encadenados, el montaje paralelo y el montaje alternado, así como el particular modo de montar la banda de sonido y la banda de imagen en algunas ocasiones -como la comentada anteriormente-, contribuyen a la expresión cinematográfica de la simultaneidad del vínculo (Levitt y Glick Schiller, 2004) característica de la experiencia migratoria. Estos elementos formales también colaboran a la conexión de actores sociales más allá de los confines de un Estado-nación, configurando una experiencia de comunidad que excede los límites de las fronteras (en el ejemplo desarrollado, una misma

\footnotetext{
${ }^{19}$ Coincide con nuestra interpretación lo expuesto por Isolina Ballesteros, quien señala que: "Uno de los elementos fundamentales de Balseros es la estructura dialógica que reproduce la comunicación entre los sujetos inmigrantes en los Estados Unidos y sus familiares en Cuba, y la intermediación sutil pero autoconsciente de los cineastas en el establecimiento y la continuidad de dicha comunicación” (Ballesteros, 2012: 68).
} 
secuencia tiende lazos que unen Guantánamo-La Habana-Miami) y en la que participan tanto aquellos que se mueven como quienes no lo hacen. Si la mediación de la cámara que registra sobre el soporte de video las imágenes que circulan a través de las fronteras hace posible la comunicación entre familiares, el empleo particular de los elementos del lenguaje cinematográfico (primeros planos para captar las emociones de los emigrados al momento de dirigirse a sus familiares o las de estos al recibir las comunicaciones, el uso de travellings y panorámicas en la mostración de los lugares vividos y, sobre todo, un montaje que busca fusionar experiencias, tiempos y espacios) conduce a la construcción cinematográfica de una comunidad que excede los límites de un Estado-nación.

El film deja entrever que los realizadores comienzan entablando una relación estrecha con cada familia en Cuba, que les permite acceso a situaciones de mucha intimidad. Más adelante, cuando se efectiviza el acto de emigrar, como ya hemos señalado, comienzan a funcionar como facilitadores de la comunicación entre los que se fueron y los que permanecieron en territorio cubano. Sobre estos aspectos, uno de los directores del documental, Carles Bosch, se expresó en una entrevista señalando que "cada vez que encontraba a mis personajes o a sus familias ellos me abrazaban efusivamente. Yo significaba algo para ellos, tal vez uno de los últimos recuerdos de Cuba, o la relación con un hijo distante" (en González Breijo, 2014: párr. 15). Respecto al uso de los videos, comenta que "el recurso no es más que una muestra de transparencia en el proceso de realización” (ídem) ya que dadas las dificultades en la comunicación entre Cuba y Estados Unidos "no es una novedad que cualquier viajante haga de mensajero" (ídem). Lo que diferencia a Bosch y Domènech de "cualquier viajante" es que son ellos mismos quienes se encargan de hacer el registro, accediendo con cámaras a espacios a los que de otro modo no hubiera sido posible ingresar (Guantánamo) y propiciando la reactivación de la comunicación en casos en los que se había disipado (Oscar y su familia, por ejemplo).

En los primeros tramos del film se emplean dos tipos de procedimientos para contextualizar la situación político-social de crisis en la que se encuadrarán las historias individuales y familiares que se procederá a narrar. Por un lado, las posturas del gobierno cubano y del estadounidense son incorporadas a la narración a partir de fragmentos de noticieros televisivos en los que se ve a Fidel Castro y Bill Clinton haciendo declaraciones en torno a lo sucedido. También se incluye información brindada a través de la radio por un locutor de noticias. Así, el discurso político-diplomático oficial es repuesto siempre a través de la recuperación de archivo de medios de comunicación de masas. Por otro lado, los propios protagonistas, antes de sernos presentados, narran en voz over los incidentes que tuvieron lugar en agosto de 1994 en La Habana mientras se suceden imágenes que demuestran lo que es relatado oralmente. En este sentido, por ejemplo, se muestran imágenes de largas colas para tramitar el visado que permita viajar legalmente a Estados Unidos a las que se superpone la voz de uno de los protagonistas del film, quien explica los problemas persistentes que los solicitantes enfrentan para que les otorguen las visas. Aunque acabamos de utilizar el término "explicar", creemos que el documental de Carles Bosch y Josep María Domènech más específicamente se dedica a hacer un seguimiento, a observar, a escuchar, a hurgar y a explorar. Si bien los directores asumen una postura en torno al problema abordado, no parecen interesados en brindar una respuesta última y unívoca, sino que más bien se sumergen en la mostración de múltiples perspectivas, lo cual resalta 
la complejidad de los procesos migratorios. En este sentido, la voz del documental parece ser abierta (Plantinga, 1997).

Balseros, a su vez, recurre a estrategias propias de lo que Bill Nichols llama modo de representación interactivo o participativo, apoyando fuertemente la argumentación en los testimonios de los actores sociales. Se produce también una sensación "de presencia situada y de conocimiento local que se deriva del encuentro real entre el realizador y otro" (Nichols, 1997: 79 _ cursivas en el original-) ya que, si bien los cineastas no aparecen físicamente en cuadro, ${ }^{20}$ en las ocasiones en que sus voces se oyen desde fuera de campo éstas se dirigen a los actores sociales captados por la cámara y no al espectador. En este sentido, no es la voz propia de los documentales expositivos o performativos (Nichols, 2001) que -incorporada al metraje en la instancia de post producción- presenta un discurso al público, sino que surge del mismo contexto en que se capturan las imágenes y en este sentido da cuenta de la situación de encuentro entre realizador y actor social, de la participación activa del director en los hechos que se están registrando. En Balseros, son los realizadores quienes tienen presencia efectiva tanto en Cuba como en Estados Unidos y circulan entre un punto y otro llevando y trayendo objetos, presentes, cartas, mensajes, historias, anécdotas y, sobre todo, registros audiovisuales. Incluso en algunas escenas, en las que amigos y vecinos dialogan con los inmigrantes, proveyéndonos información de sus relaciones en destino y de su día a día e intensificando la sensación en el espectador de acceso irrestricto a la cotidianidad de los protagonistas de la historia, podríamos pensar en la presencia activa de los realizadores a través del uso de la "entrevista encubierta" (Nichols, 1997: 87), en la que el entrevistado no se dirige al realizador, sino que entabla conversación con otro actor social. En este tipo de "conversación implantada" (Nichols, 1997: 88) tanto el tema como el devenir de la charla fueron preestablecidos. Si bien se trata sólo de una hipótesis, podríamos pensar que en estas escenas nos encontremos ante este tipo de diálogos.

En los documentales interactivos / participativos se incrementan las posibilidades del realizador de "actuar como mentor, participante, acusador o provocador en relación con los actores sociales reclutados para la película" (Nichols, 1997: 79). Creemos que es justamente esta capacidad de los realizadores de actuar como partícipes y provocadores la que nos permite proponer la hipótesis de que hayan colaborado en la configuración de un campo social transnacional al intervenir y aceitar los vínculos entre origen y destino. Esto se explicita permanentemente en el transcurso del film. En una escena, mientras Juan Carlos y Misclaida eligen un automóvil que planean comprar, los directores intervienen desde fuera de campo para provocar un acercamiento entre la pareja, que en ese momento discutía en torno a cómo solía ser su vida en Cuba y cómo era en la actualidad. En otra escena acompañan a Miriam a elegir un regalo para su hija y luego participan del momento en que la niña lo recibe en Cuba (Imágenes 3 y 4). En el último caso, las dos imágenes son montadas a través de un fundido encadenado. Esta decisión formal genera una sensación de continuidad entre ambas acciones y espacios.

${ }^{20}$ Hay un breve instante, en apariencia no buscado, en que se puede distinguir a uno de los directores en cuadro. 


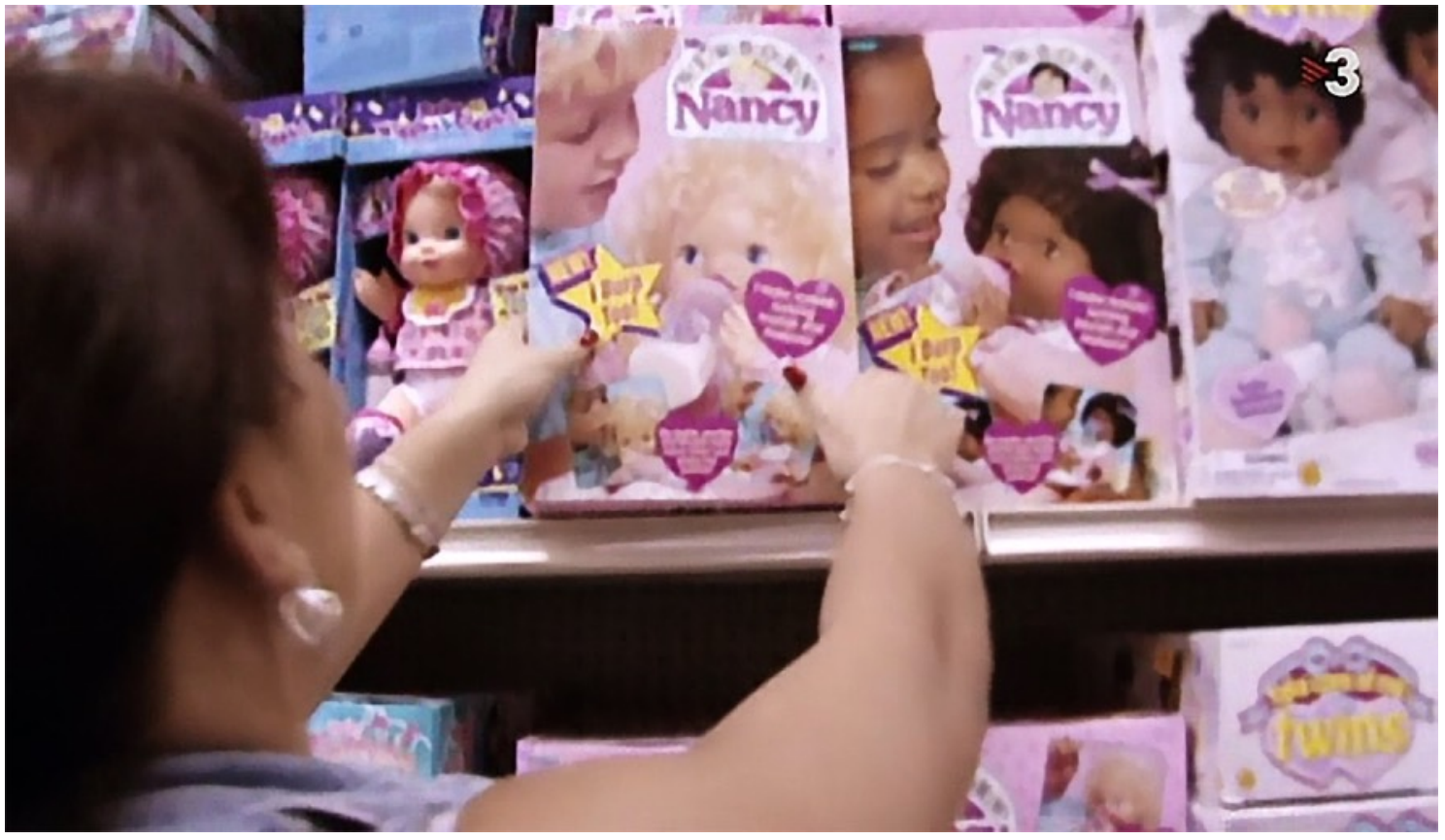

Imagen 3: Miriam elige el regalo para su hija en Estados Unidos.

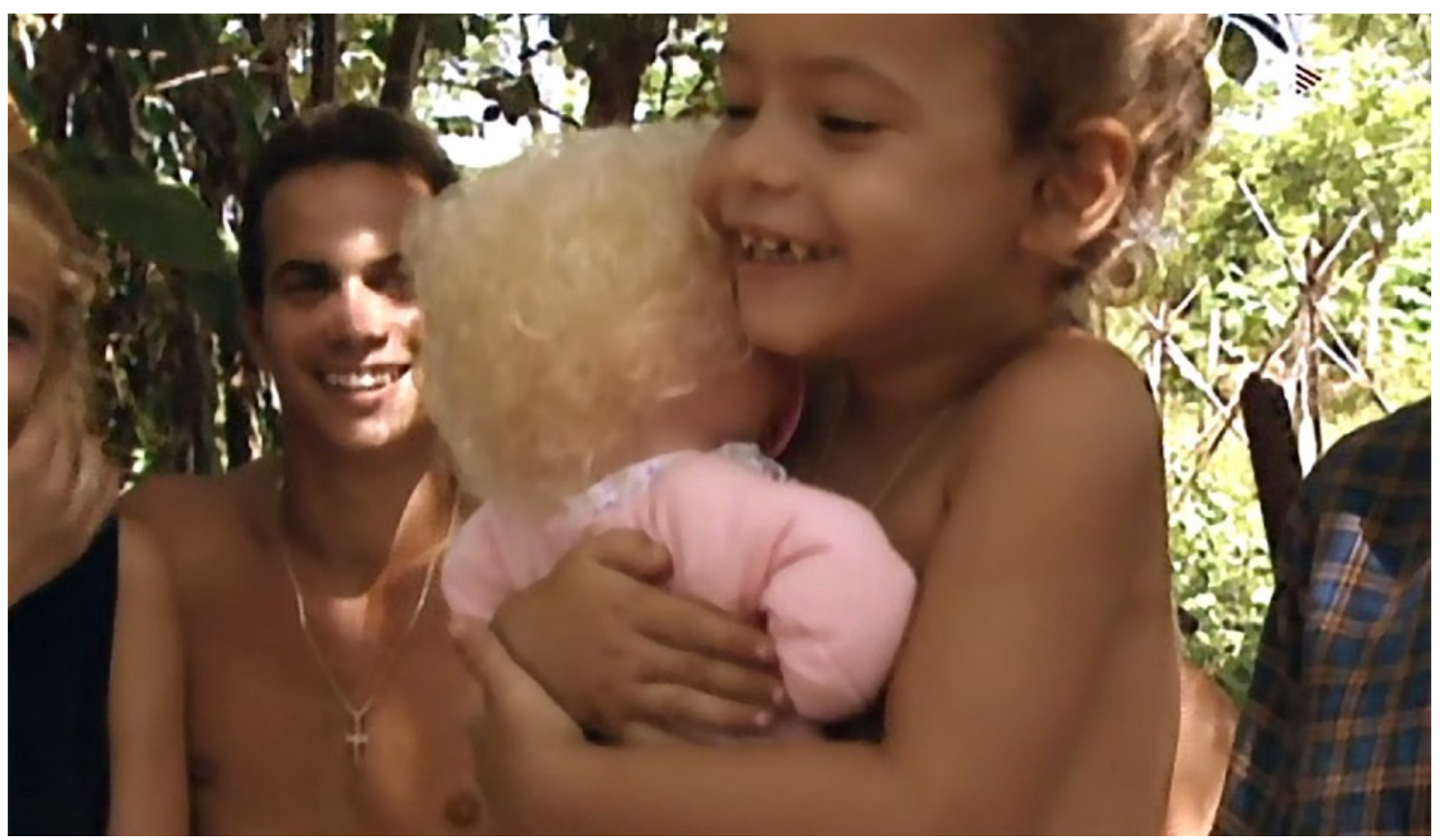

Imagen 4: La hija de Miriam recibe el obsequio en Cuba.

El acceso a situaciones de suma intimidad de los actores sociales y la sensación de intrusión en sus vidas cotidianas que esto favorece indica el recurso a ciertas estrategias propias de los documentales de observación (Nichols, 1997, 2001). Lo que distancia a Balseros de la caracterización propia de estos documentales es la marcada intervención de los directores y su explicitación permanente, entre otras cosas, a través del uso de diversas técnicas de montaje, por medio del cual no sólo se construye el ritmo de la película, sino que también se vehiculizan 
opiniones. Lo mismo se puede decir de la banda musical, compuesta por canciones que resaltan rasgos de los distintos protagonistas y que los caracterizan a lo largo del film. La primera aparición de estos motivos musicales surge por dos vías: está inspirada por lo que dice alguno de los sujetos ("un carro, una casa, una buena mujer", en el caso de Rafael) o bien por alguno de los objetos que aparece en cuadro (Virgen de la Caridad del Cobre, en el caso de Guillermo).

Como se señaló al comienzo, una serie de conceptos provenientes de los estudios sobre migraciones transnacionales nos permiten pensar ciertos aspectos de este documental. En varios de los mensajes intercambiados entre familiares se habla de una futura reunificación familiar. Se trata de los casos de Oscar, Guillermo y Miriam. De este modo, sus proyectos migratorios no se configuran como individuales sino como familiares. Nuevamente aquí, la intervención de los realizadores en tanto transmisores de comunicaciones audiovisuales entre Cuba y Estados Unidos (y, eventualmente, Guantánamo) será esencial en la construcción cinematográfica del proceso migratorio. El destino de cada proyecto migratorio será disímil.

El de Oscar se verá frustrado. Sabemos al comienzo que él emigra encabezando un proyecto migratorio familiar. Su esposa e hija permanecen en La Habana a la espera de recibir remesas y luego, por vías menos peligrosas que el viaje en balsa, también emigrar. Pero prontamente Oscar asumirá su emigración como individual, intentará agenciarse nuevos vínculos en destino y desestimará progresivamente la comunicación con su familia en La Habana. Como habíamos afirmado que señalan Levitt y Glick Schiller (2004) a propósito de ciertas experiencias migratorias, Oscar decide dejar de lado algunos de sus vínculos familiares. Su partida, al comienzo del film, se constituye como célebre y heroica por quienes lo conocen y acompañan en el trayecto hacia el mar. Un plano general permite apreciar la multitud que festivamente despide al grupo que se traslada en camioneta a la costa. En el plano posterior, a partir de un travelling se da cuenta de cómo un gran número de personas en bicicletas escolta el trayecto del vehículo. Si bien estas imágenes son acompañadas por la voz de su hermana, sobre el final comienza a escucharse la música melancólica de un piano, que acompañará luego a las imágenes correspondientes a la partida de la balsa. Aunque esta musicalización extradiegética podría prever un futuro poco promisorio, en los testimonios que la anteceden y suceden se asume que la emigración de Oscar traería implícito un mejor futuro para el grupo familiar. A medida que avanza el film, se demuestra que esto no es lo que sucede por lo general (y particularmente en este caso). Esa idealización de las posibilidades que los emigrados tendrían en destino -contradicha luego por sus experiencias efectivas- parece indicar una deficiencia en la información que manejan aquellos que anhelan emigrar. Apenas llegado a Estados Unidos, el film pone en escena un episodio de (in)comunicación con su esposa. Ella imagina en La Habana un futuro cercano promisorio, con una heladera llena de víveres. Él parcamente le informa que debe ocuparse primero de sí mismo y "olvidar". Incluye palabras en inglés en ese intercambio, intensificando la distancia y la imposibilidad de comunicación. Al poco tiempo, Oscar tiene una nueva mujer. Cuando la trama lo reencuentre cinco años después, habrá cortado contacto con la familia en La Habana. Se explicita nuevamente aquí la labor de los cineastas en la comunicación entre origen y destino: Oscar recibe información sobre su hija por medio de los realizadores, quienes le acercan imágenes en video (Imágenes 5 y 6). Se pone así de manifiesto una vez más la mediación del dispositivo audiovisual en la construcción de un campo social transnacional: son las imágenes en video, que constituyen parte del propio documental, las que restituyen la comunicación entre 
origen y destino. Si bien este personaje intenta ejercer un quiebre, cortar con el pasado en Cuba y tener un nuevo comienzo en Estados Unidos, los realizadores parecen querer destacar cómo tal corte no es completamente posible al devolver al relato (y al propio emigrado) un pasado que, de un modo u otro, aún pende en el presente. Al mostrar al emigrado que intentó un nuevo comienzo videos de su hija en Cuba y al narrar a la familia en Cuba el devenir del emigrado, los directores enfatizan la imposibilidad de segar trayectorias o, al menos, resaltan que los cortes jamás pueden hacerse con precisión quirúrgica, sino que siempre quedan trazos vinculantes. Se infiere que, para esto, Bosch y Domènech deben haber desarrollado una fuerte cercanía e intimidad con los protagonistas y sus familiares, que les permitió acceso a sus hogares y a su cotidianidad. ${ }^{21}$ También se valieron de las posibilidades del dispositivo cinematográfico: a través del fundido encadenado y del montaje paralelo en las escenas de visionado de los videos, restablecen las costuras que aún unen las instancias de origen y destino, más allá de las voluntades personales de los individuos involucrados.

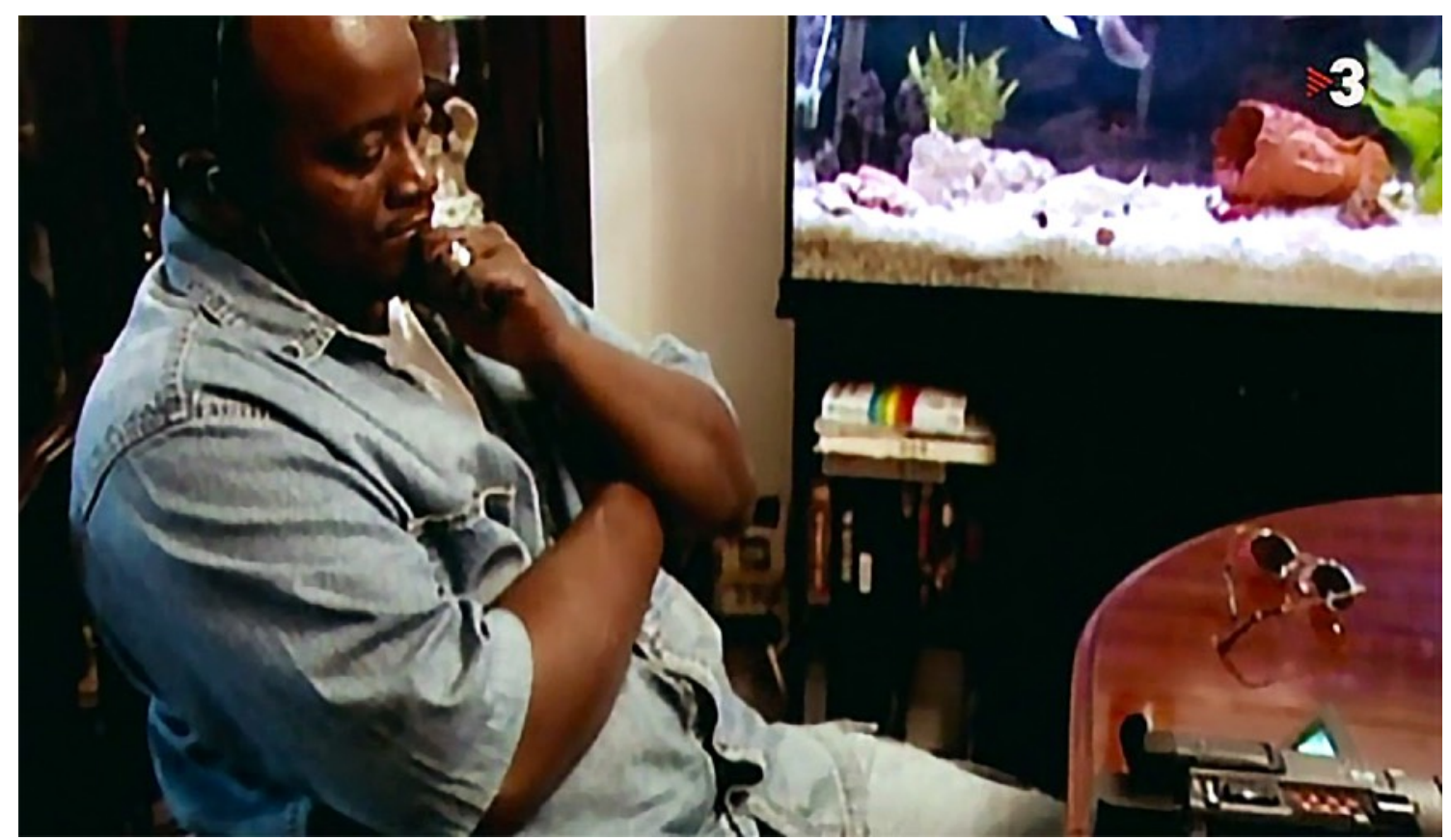

Imagen 5: Oscar mira un video con imágenes de su hija, a quien no contactaba en años.

\footnotetext{
${ }^{21}$ Consultado en una entrevista en torno a la soltura de los actores sociales en Balseros, Carles Bosch expresó que: "Eso es normal. Mis personajes normalmente están viviendo situaciones en las que todo lo demás les importa un pepino. Al revés, en un momento dado hasta pueden sentirse algo más suaves con nuestra presencia, y ya no digamos si encima se van acostumbrando. Si, además, tienes un camarógrafo casi transparente, gente muy callada que cae muy bien sin necesidad de haber hecho una gran amistad, es mucho más fácil” (Reguant y Abeillé, 2014: 6).
} 


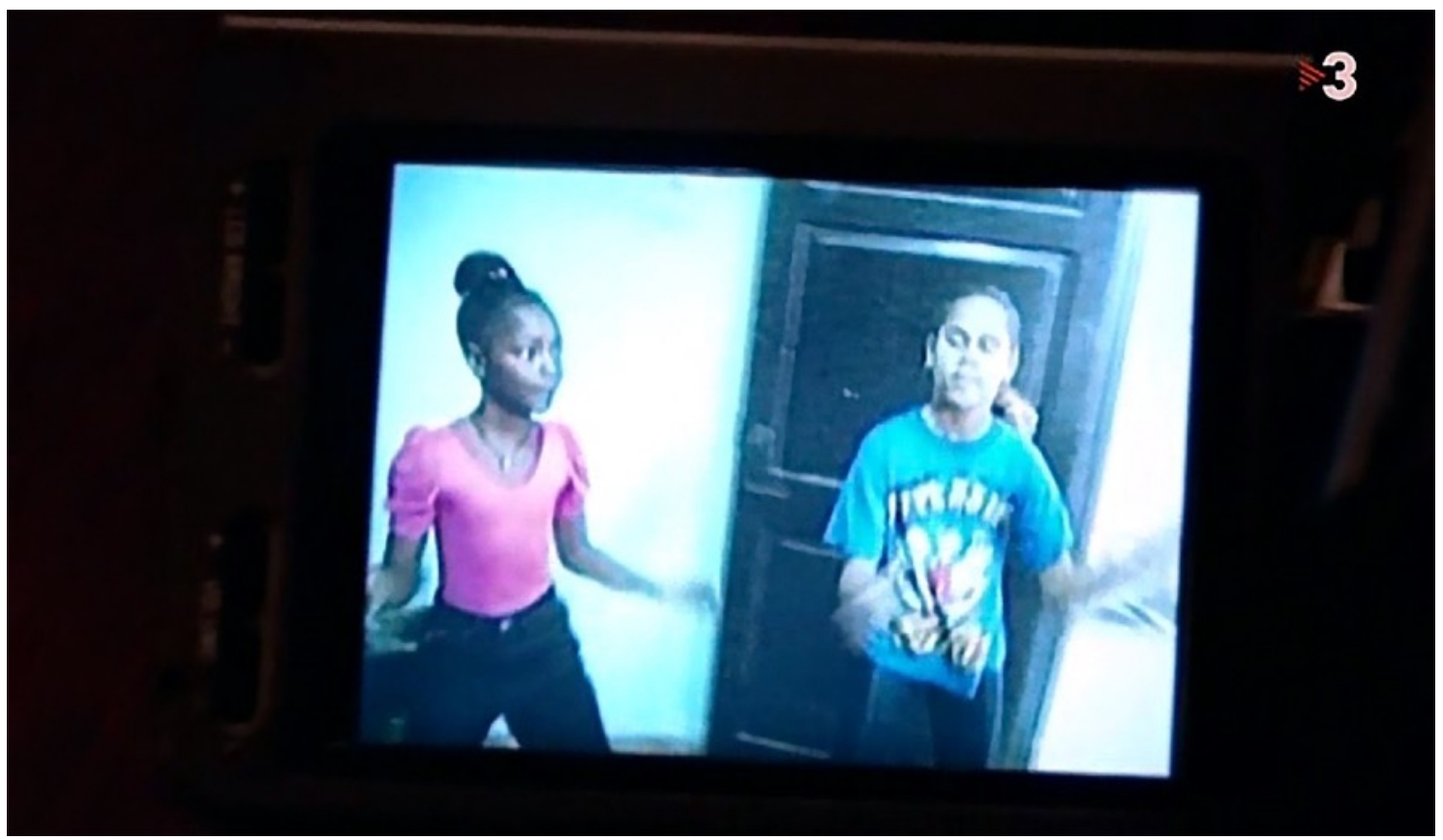

Imagen 6: Video de la hija, mostrado a Oscar por los directores del film en el visor de la cámara.

El proyecto migratorio familiar de Guillermo, por el contrario, será exitoso. Su esposa e hija habían emigrado con anterioridad, encabezando el proyecto, y él debía unírseles posteriormente, cosa que logra una vez abandona Guantánamo. La construcción de su personaje gira en torno al objetivo de la reunificación. La estrategia migratoria familiar, que había tenido como puntapié inicial un divorcio que permitió la emigración legal de la esposa y la hija (reclamadas por su madre, residente en Estados Unidos) contemplaba el viaje posterior de Guillermo, aunque no el modo en que habría de lograrlo. La consecución de este objetivo se vio dificultada por el accionar de la Sección de Intereses de los Estados Unidos en Cuba, que le negó el visado en cada una de las ocasiones en que lo solicitó. En su discurso se pone de manifiesto como en ningún otro caso que es esta negativa la que lo obliga a emigrar de forma ilegal. Mientras que, en el caso de Oscar, los directores intervienen de modo persistente en el tejido de una red que lo una con La Habana, llevando y trayendo materiales audiovisuales e información, en el caso de Guillermo lo que nos es mostrado de su vida familiar en Estados Unidos es casi lo justo y necesario para denotar una suerte de "asimilación" a la cultura estadounidense, a la american way of life: él trabaja como repositor en una gran tienda y su hija casi no puede hablar en español. El grado de protagonismo de esta historia disminuye en la última parte del film. Consideramos que esto se vincula con la hipótesis de la preminencia de los directores y el dispositivo cinematográfico en el establecimiento de vínculos entre origen y destino: una vez lograda la reunificación, Guillermo y su familia se encuentran juntos en Estados Unidos. Su historia, entonces, parece seguirse en función de brindar información al espectador y no ya como vía para la comunicación entre familiares.

La lucha de Miriam por recuperar a su pequeña hija, que permaneció en Cuba, se desarrollará a lo largo de todos los años compendiados en el film. Esta estrategia migratoria familiar es interesante para pensar el concepto de maternidad transnacional (Hondagneu-Sotelo y 
Avila, 1997), ya que es la madre quien encabeza el proyecto, dejando a su hija al cuidado de la abuela. Luego de pasar nueve meses en Guantánamo es recibida por parte de su familia en Miami. En ese momento, Miriam graba un audio para su madre: "Cuídamela, mami. Cuídamela mucho", repite, refiriéndose a su hija. Como ya hemos mencionado, a través del montaje, en una escena vemos cómo Miriam elige un juguete y, posteriormente, cómo la niña juega con él en Cuba, regresando sobre la idea de simultaneidad y la mediación del dispositivo cinematográfico y el accionar de los directores. Es claro que son los cineastas quienes median en la recepción de ese regalo, poniéndose una vez más de manifiesto su rol activo en la configuración de vínculos particulares: la niña y los familiares que permanecen en origen pueden ser testigos de las imágenes del momento en que la madre elige el regalo para su hija y Miriam puede a su vez apreciar a través de las imágenes registradas por los cineastas el momento en que la niña lo recibe. Esto resalta una vez más el importante papel desempeñado por el propio dispositivo cinematográfico en la constitución del campo. Una estrategia similar es puesta en juego en otra escena, en que los realizadores montan primero una toma de la niña corriendo y luego a la madre viendo ese registro en su hogar estadounidense. En el video, en un momento, la niña cae, y la madre reacciona como si pudiera ayudarla a volver a ponerse en pie. Las distancias físicas y temporales parecen borrarse en la construcción fílmica propuesta por los cineastas. Finalmente, esto se reitera en un llamado telefónico que ambas sostienen cuando la niña ya se encuentra en edad escolar. Como se ha señalado previamente, a partir del progresivo fundido encadenado del plano de cada una al teléfono se constituye una imagen afín a la de pantalla partida (sin una separación neta entre ambas imágenes) que enfatiza la fluidez y la simultaneidad.

El film nos permite pensar también en las redes y cadenas migratorias (Pedone, 2010). Oscar, Juan Carlos y Misclaida, quienes no tienen familiares en Estados Unidos, son acogidos por redes. Se trata específicamente de asociaciones religiosas que se encargan de la recepción de los inmigrantes: los ubican en distintas ciudades y les proveen casa y empleo. Sobre el final Méricys, aunque su hermana Misclaida hubiera llegado antes, es recibida también por la misma red. Se repiten en varias escenas las palabras con las cuales la encargada de recibirlos les indica en qué ciudad se los ubicará. El discurso es idéntico y, aunque entusiasta, mecánico: sólo cambia el nombre de la ciudad. Rafael, Miriam y Guillermo, en cambio, son recibidos por cadenas: tíos en los dos primeros casos y la mujer y la hija en el segundo. En el seguimiento de Juan Carlos y Misclaida, una escena pone de manifiesto nuevamente cómo los cineastas contribuyen a la construcción de un campo social transnacional, al mostrar primero cuando ambos escriben una carta a sus familiares y luego cómo éstos reciben en Cuba la carta y ven el video del momento en que la están escribiendo (Imágenes 7 y 8). 


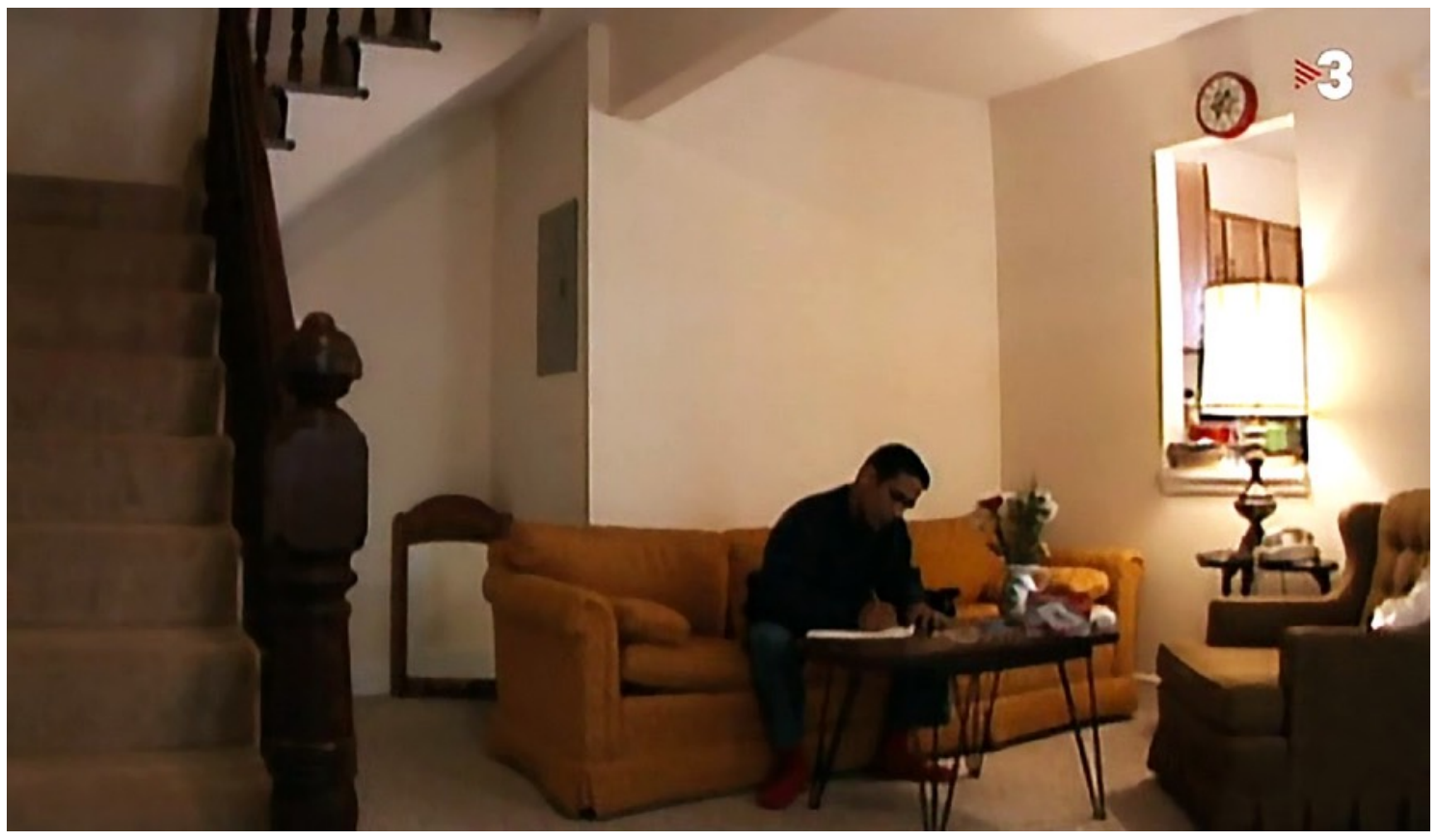

Imagen 7: Juan Carlos escribe una carta para su familia en su casa en Estados Unidos.

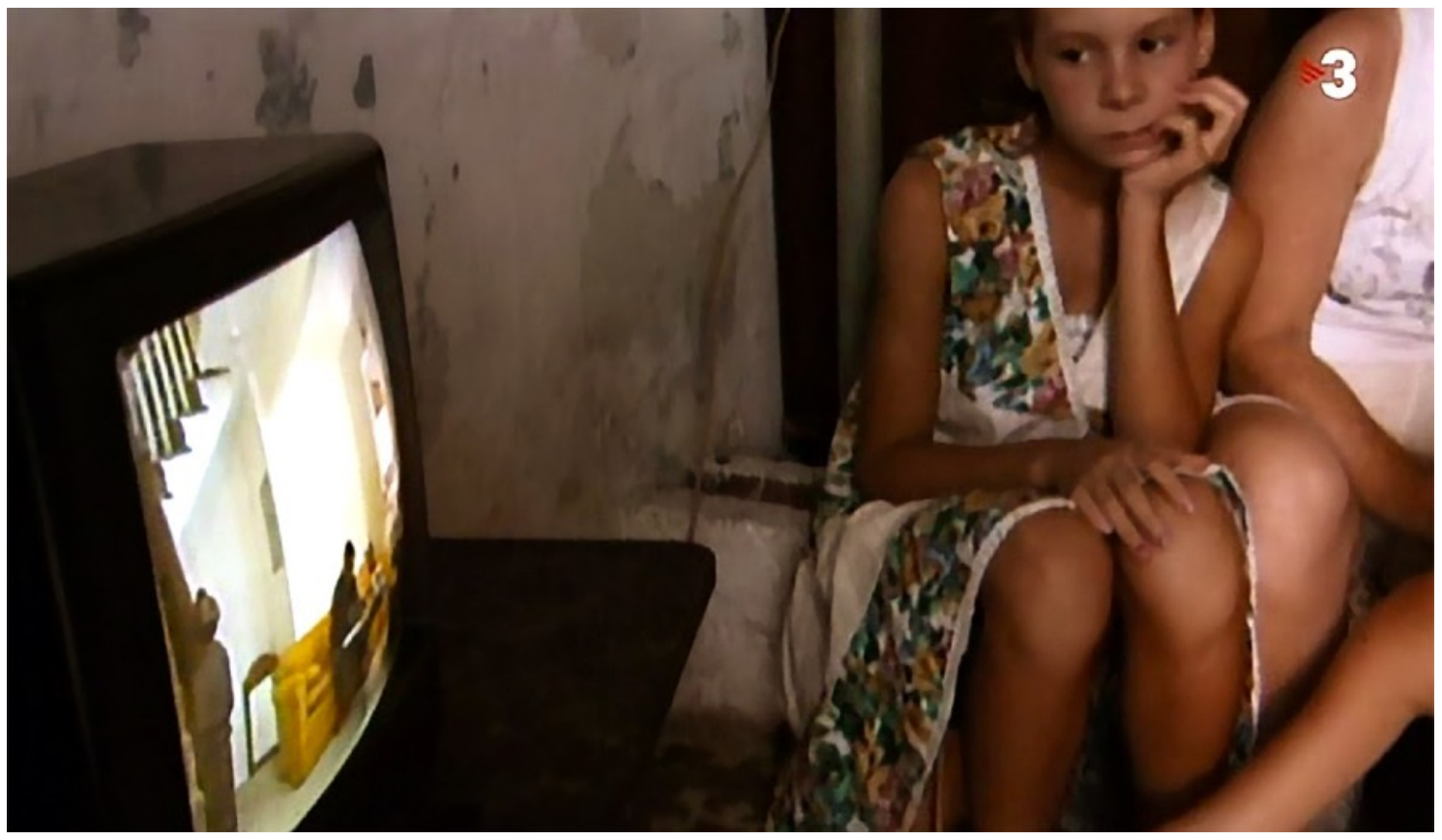

Imagen 8: La familia de Juan Carlos recibe en La Habana no sólo la carta, sino que también mira el video del momento en que ésta estaba siendo escrita. 


\section{A MODO DE CIERRE}

Carles Bosch y Josep María Domènech acompañaron el proceso migratorio de siete actores sociales y colaboraron en el mantenimiento del vínculo de esos emigrados con sus familiares, principalmente a través de la captura y la puesta en circulación de registros audiovisuales. Luego de acompañar su intento frustrado de salida de Cuba, su detención en Guantánamo y su llegada a Estados Unidos, los directores decidieron volver en su búsqueda cinco años después. La acción de los cineastas facilitó unos intercambios tal vez no tan fácilmente viables, debido a los condicionamientos existentes en las posibilidades de comunicación efectiva entre Cuba y Estados Unidos. Así, los que se fueron y los que se quedaron se relacionaron a través de los videos, las cartas y las llamadas telefónicas que circulaban entre ellos con la mediación de los realizadores y del dispositivo audiovisual. Esta mediación hizo que los mecanismos de comunicación adquirieran características especiales, ya que las cartas no eran simplemente recibidas y leídas en destino, como hubiera sucedido en el caso de una comunicación epistolar habitual, sino que los familiares en Cuba además pudieron presenciar el momento preciso en que los emigrados las escribían. Esto sólo fue posible a partir de la intervención de los realizadores y la mediación del dispositivo. De acuerdo a declaraciones citadas a lo largo de este artículo, tomadas de entrevistas a Carles Bosch publicadas en distintos medios, los directores parecen haber desarrollado un vínculo emocional con los actores sociales involucrados en el film, logrando además un acceso privilegiado a las situaciones íntimas a través de lo que el realizador define como "un camarógrafo casi transparente" (Reguant y Abeillé, 2014: 6). Si bien Bosch ha sostenido, en torno al recurso del uso de videos, que, dadas las dificultades en la comunicación entre Cuba y Estados Unidos, "no es una novedad que cualquier viajante haga de mensajero" (en González Breijo, 2014: párr. 15), en este artículo se considera que la labor de los realizadores difiere de la que podría efectuar "cualquier viajante" que "haga de mensajero". Bosch y Domènech no se limitaron a cargar en sus valijas videos que recibían y entregaban a un lado y al otro del estrecho de Florida, sino que tuvieron una participación que excedía en mucho a esa simple acción. En realidad, los cineastas participaron activamente en el registro -e incluso en la provocación- de sucesos en origen y destino. Para pensar esto acudimos, a lo largo del artículo, al concepto de campo social transnacional, acuñado por Peggy Levitt y Nina Glick Schiller (2004), que hace referencia a las relaciones que se establecen entre origen y destino, y que incluyen tanto a quienes se desplazan como a quienes no lo hacen, comprendiendo a los procesos migratorios más allá de su experiencia directa. Se considera, por lo tanto, que, en el caso de este film, los cineastas y el dispositivo cinematográfico tendieron hilos entre Cuba y Estados Unidos a través de su actividad de realización documental y colaboraron, de tal forma, en la conformación de dicho campo. Si bien la estancia en Guantánamo es el momento en que esto se vuelve notoriamente evidente, dado que nadie más hubiera podido captar y hacer llegar esos registros en video, el procedimiento se repite a lo largo del film.

Los elementos narrativos propios de los documentales interactivos o participativos (Nichols, 1997; Weinrichter, 2004) que se despliegan en Balseros contribuyen a la construcción de un texto cinematográfico que resalta este accionar, al poner el acento tanto en los testimonios de los actores sociales como en la participación de los cineastas en los eventos registrados. El montaje es otro elemento significativo a partir del cual el propio texto fílmico contribuye a la 
ligazón entre origen y destino: el repetido empleo de los fundidos encadenados, del montaje paralelo, del montaje alternado, y de la yuxtaposición de la banda de sonido registrada en un espacio geográfico con la imagen registrada en otro, colaboran a una construcción cinematográfica de los procesos migratorios que expresa la conexión de actores sociales más allá de los confines de un Estado-nación, configurando una comunidad de la que participan tanto aquellos que emigran como quienes no lo hacen. Si los registros en video y la circulación de los mismos en manos de los directores hace posible la comunicación entre familiares, el empleo de los elementos del lenguaje cinematográfico mencionados conduce a la construcción cinematográfica de una comunidad que excede los límites de un Estado-nación. El registro de imágenes en origen y destino y los tipos de montaje efectuados sobre las mismas, ponen de manifiesto esa cualidad identitaria conceptualizada por Alain Tarrius (2000), que permite a los sujetos ser de aquí y de allá a la vez. ${ }^{22}$ De este modo, creemos que el proceso de construcción cinematográfica de la migración incide a su vez en la constitución efectiva de los procesos migratorios.

Asimismo, el carácter transnacional del film aporta una lectura alternativa a la de otras producciones, sean estas netamente cubanas o incluso coproducciones con España, pero realizadas por directores cubanos. En este sentido, como se señaló al principio, resulta indispensable pensar en el concepto de transnacionalismo afinitivo propuesto por Mette Hjort (2009). Al momento de realización de Balseros, la problemática migratoria distaba de ser ajena o indiferente para la sociedad española. El propio Carles Bosch señaló en una entrevista brindada al diario El país que las historias narradas en el film podrían también simbolizar las experiencias de los marroquíes que cruzan el Estrecho de Gibraltar, pero ponía en duda si los espectadores españoles hubieran aceptado un film sobre ese tema del mismo modo en que aceptaron Balseros (Ramos Martín, 2003). Se considera, entonces, que el transnacionalismo en esta película se explica en gran medida a partir del descubrimiento de una cuestión propia de las relaciones cubanoestadounidenses, pero que resultaba relevante para provocar a su vez la reflexión en torno a problemas vivenciados en el contexto español.

\footnotetext{
22 Esta cualidad se desarrolla plenamente en Amor crónico (Jorge Perugorría, 2012). Hemos planteado algunas ideas al respecto en el artículo "Migración y cubanidad en el cine: una historia de abrazos" (2016).
} 


\section{BIBLIOGRAFÍA}

AlmazÁn Del Olmo, Sonia (2007). "Cine, emigración e identidad: claves para la interpretación de la cultura cubana”. Ponencia presentada al XXVII Congreso de LASA. Canadá.

Alonso TejadA, Aurelio (2006). El laberinto tras la caída del muro. La Habana: Editorial de Ciencias Sociales.

Anderson, Benedict (1993). Comunidades imaginadas. Reflexiones sobre el origen y la difusión del nacionalismo. México: Fondo de Cultura Económica.

Arboleya Cervera, Jesús (2013). Cuba y los cubanoamericanos. El fenómeno migratorio cubano. La Habana: Fondo Editorial Casa de las Américas.

BALLESTEROS, Isolina. "La inmigración económica latinoamericana en el documental Europeo de inmigración: Balseros (2002), Del otro lado (2002) y Familia (2010)”. Migraciones y Exilios 13 (2012): 63-82.

Bosch, Carles y Doménech, José María (2002). Balseros. España: Bausan Films, Televisió de Catalunya (TV3) y Buenavida Producciones S.L.

Castro Avelleyra, Anabella. "Migración y cubanidad en el cine: una historia de abrazos". Cine Cubano 200, septiembre-diciembre, (2016): 30-39.

DíAZ, Désirée. "La mirada de Ovidio. El tema de la emigración en el cine cubano de los 90". Temas 27 (2001): 37-52.

DíAZ, Désirée (2008). "Los otros. Exilio y emigración en el cine de la Revolución”. Berthier, Nancy (ed.). Cine y revolución cubana: luces y sombras. Valencia: Archivos de la Filmoteca.

FORNET, Ambrosio (2000). "La diáspora como tema". Memorias recobradas. Introducción al discurso literario de la diáspora. Santa Clara: Ediciones Capiro.

GonzÁlez Breijo, Nelson. "Con el director de Balseros". Progreso semanal. 28 de octubre de 2014.

HigbeE, Will y Lim, Song Hwee, "Concepts of transnational cinema: towards a critical transnationalism in film studies”, Transnational cinemas, Volume 11 (2010): 7-21.

HJORT, Mette (2009). "On the plurality of cinematic transnationalism". DuroviCOVÁ, Natasa y Newman, Kathleen (eds.). World Cinemas, Transnational Perspectives. Abingdon, Oxon: Routledge.

Hondagneu-Sotelo, Pierrette y Avila, Ernestine. “'I'm here, But I'm there': The Meanings of Latina Transnational Motherhood”. Gender and Society 5 (1997): 548-571.

LEVITT, Peggy y GLICK SCHILLER, Nina. "Perspectivas internacionales sobre migración: conceptualizar la simultaneidad". Migración y Desarrollo 3 (2004).

LEVITT, Peggy (2010). "Los desafíos de la vida familiar transnacional". Grupo INTERDISCIPLINARIO DE INVESTIGADOR@s MIGRANTES (coords.). Familias, niños, niñas y jóvenes migrantes: rompiendo estereotipos. Madrid: IEPALA-Caja Madrid Obra Social Casa Encendida. 
LÓPEZ BLANCH, Hedelberto (1998). Descorriendo mamparas. La emigración cubana en Estados Unidos. La Habana: Editorial SI-MAR S.A.

NiCHOLS, Bill (1997). La representación de la realidad. Cuestiones y conceptos sobre el documental. Barcelona: Paidós.

NiCHOLS, Bill (2001). Introduction to documentary. Bloomington: Indiana University Press.

ORTIZ, Fernando (1978). Contrapunteo cubano del tabaco y el azúcar. Caracas: Fundación Biblioteca Ayacucho.

PEDOnE, Claudia. "Cadenas y redes migratorias: propuesta metodológica para el análisis diacrónico-temporal de los procesos migratorios". Empiria. Revista de Metodología de Ciencias Sociales 19 (2010): 101-132.

Plantinga, Carl (1997). Rethoric and representation in nonfiction film. Cambridge: Cambridge University Press.

Ramos Martín, Manuel. "Entrevista a Carles Bosch. Reportero y director de 'Balseros': 'El documental en televisión necesita una revolución formal"'. El país. 14 de diciembre de 2003.

Reguant, Mar y ABeillé, Constanza. "La tarea del documentalista. Entrevista con Carles Bosch”. Revista Imagofagia 9 (2014). Buenos Aires.

TAL, Tzvi (2011). "Imágenes prostituidas: inmigrantes latinoamericanas en «Princesas»y «En la puta vida»". Schammah Gesser, Silvina y Raanan Rein (coords.). El otro en la España contemporánea / Prácticas, discursos y representaciones. Sevilla: Fundación Tres Culturas del Mediterráneo.

TARrIUS, Alain. "Las circulaciones migratorias: conveniencia de la noción de 'territorio circulatorio'. Los nuevos hábitos de la identidad”. Revista Relaciones 83 (2000). Michoacán.

VilLaR-Hernández, Paz. "El Otro: conflictos de identidad en el cine español contemporáneo”. Graduate Romanic Association Volumen 6 (2002). Pensilvania: University of Pennsylvania.

Weinrichter, Antonio (2004). Desvios de lo real. El cine de no ficción. Madrid: T/B Editores. 